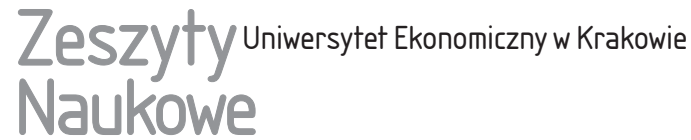

Roman Kopych

Ivan Franko National University of Lviv

Iryna Bardyn

Lviv Academy of Commerce

\section{Domestic and External Demand Shocks in Ukraine}

\begin{abstract}
Persistent budget deficits and extremely high interest rates (while inflation remains relatively low) have been a distinct feature of the 2010-2013 period in Ukraine. By using a statistical technique of the vector autoregressive - vector error correction (VAR/VEC) model, it is established that: a) the budget deficit is a factor behind the exchange rate depreciation and an increase in the interest rate, with a very strong contractionary effect on output; b) a higher interest rate contributes to worsening of the budget balance and a significant decrease in output (both are standard macroeconomic relationships); c) nominal exchange rate depreciation permanently widens the budget deficit, combined with a temporary increase in the interest rate and short-lived output contraction. It is worth noting that upward interest rate pressure is the only statistically significant effect of a positive output shock. According to the variance decomposition, the budget balance determines up to $50 \%$ and the interest rate upwards of $40 \%$ of changes in the output, respectively. It is confirmed that an increase in output is of marginal importance for the budget balance. On the whole, our findings argue in favour of fiscal discipline in Ukraine as a stabilisation policy tool.
\end{abstract}

Keywords: budget balance, exchange rate, interest rate, output, Ukraine. 


\section{Introduction}

An increase in the budget deficit against the backdrop of a widening current account deficit and the real interest rate hike was a distinct feature of Ukraine's economy in 2012 and 2013 (Fig. 1). Expansionary fiscal policy sought to prop up income growth, though it could not but lead to the financial crisis of 2014. Worsening of external conditions and an unfavourable gas provision contract signed with Russia in January 2009 used to be mentioned as the main explanations for stagnation in the real sector from 2011 to 2013. O. Reznykova (2014, pp. 169-174) mentions the negative impact of trade wars with Russia and decreasing remittance inflows from workers abroad. A. Vozna and Y. Zhalilo (2014, pp. 23-34) draw attention to structural deformations, which caused the deep recession of 2008-2009 and have led to a painful macroeconomic adjustment process. In a wider context, the Ukrainian economy's excessive vulnerability to external macroeconomic shocks has been caused by several factors: a) slow adjustment of the real estate bubble that emerged over the pre-crisis 2003-2008 period, b) excessive credit growth in the years 2006-2008, c) accumulation of private and public debt, and d) insufficient investment activities.

It is quite natural to suggest that a combination of unfavourable external conditions and stagnation of the real sector has led to a substantial worsening of the budget balance. However, it is not ruled out that a discreet expansionary fiscal policy has been used as an autonomic instrument of stabilisation policy aimed at preventing a deep decline in output. Potentially, a higher budget deficit has created upward pressure on the real interest rate leading to worsening of either the current account or output growth. In such a macroeconomic framework, the steep depreciation of the hryvna - to the tune of $80 \%$ - from February to October 2014 can be viewed as a natural outcome of the macroeconomic imbalance that had been created by profligate fiscal policies.

There are numerous studies that support the expansionary effects of the budget deficit on the real sector, including (Adao \& De Brito 2006, pp. 3-15; Blanchard \& Perotti 2002, pp. 1329-1368; Dai \& Philippon 2005, pp. 15-16; Romer \& Bernstein 2009, pp. 550-555), to name just a few. However, expansionary effects may also be brought about by the reduction in the budget deficit, as found by A. Alesina and S. Ardagna (2009), S. Fischer (1993, pp. 485-512), N. Gemmell, R. Kneller and I. Sanz (2007), M. Kandil (2009, pp. 133-158), R. Perotti (2002), D. Romero-Avila and R. Strauch (2008, pp. 172-191), especially in terms of how the fiscal consolidation is initiated at high levels of public debt or unsustainable budget deficits (Afonso 2010, pp. 105-109; Bergman \& Hutchison 2010, pp. 71-93; Giavazzi \& Pagano 1990, pp. 75-122; Giavazzi, Jappelli \& Pagano 2000). 


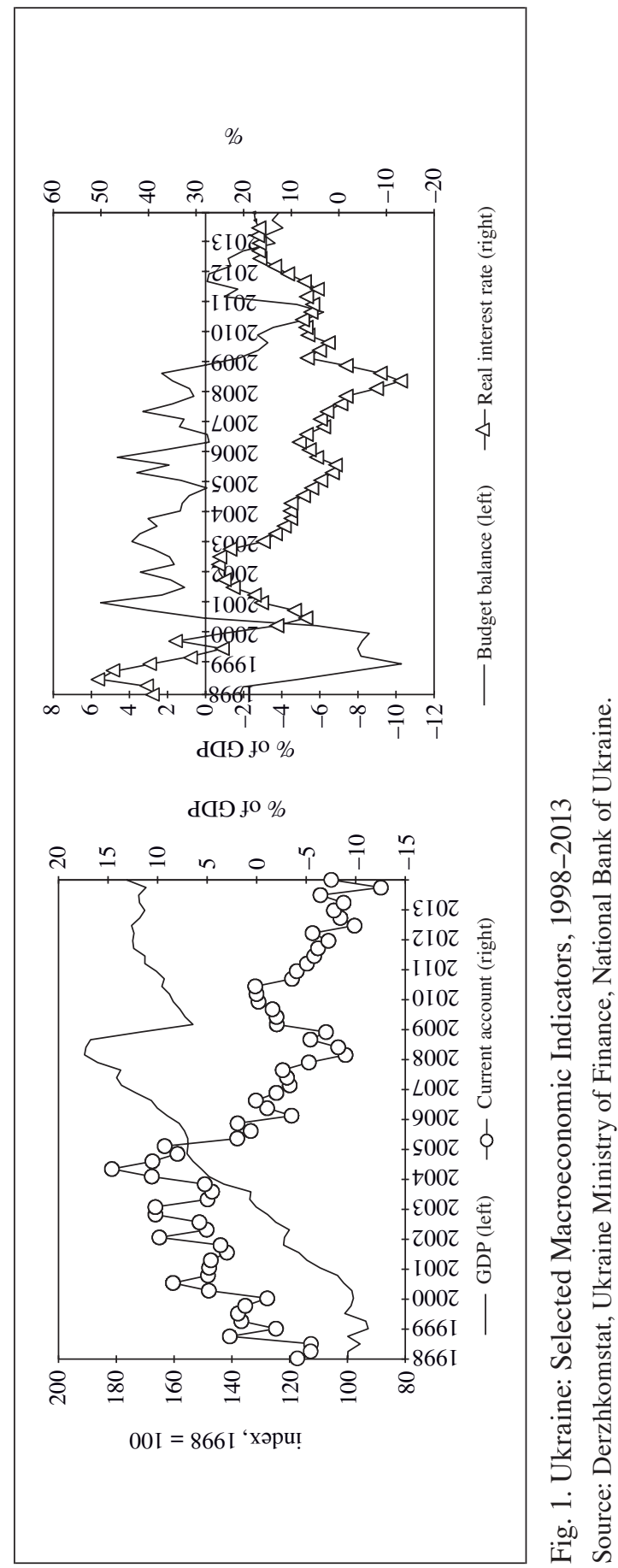


For the countries of Central and East Europe (CEE), a non-conventional expansionary effect of budget deficit cuts has been found for both panel data (Rzońca \& Ciżowicz 2005, Segura-Ubiergo, Simone \& Gupta 2006) and individual country studies for Poland (Chen 2008, pp. 49-56; Wojciechowska-Toruńska 2009, pp. 41-52), Romania (Enache 2009, pp. 502-512), the Slovak Republic (Hsing 2006, pp. 249-259), Hungary (Lendvai 2007) and Croatia (Rukelj 2009, pp. 27-58). Using industrial output as a measure of income, V. Shevchuk and R. Kopych (2010, pp. 111-121) report that the budget deficit is expansionary in the Slovak Republic, but the opposite (restrictionary) effect is obtained for Hungary, with no impact in Poland and Slovenia.

This article analyses the interplay between several important factors of internal and external demand. The budget balance, exchange rate and interest rate as factors of domestic demand are of particular interest as instrumental tools for stabilising policies as well. For the analytical interpretation of the relevant relationships, the IS-LM-BP model was used. Empirical links are estimated with the Vector Autoregression/Vector Error-Correction (VAR/VEC) method.

The structure of the article proceeds as follows. Section 2 provides an analysis of the analytical issues while Section 3 discusses the data and statistical model. Section 4 presents the empirical results, followed by the conclusions in Section 5.

\section{Analytical Framework}

Macroeconomic developments and stabilisation policies employed during the years 2010-2014 can be interpreted with the extended IS-LM-BP model that accounts for the supply-side effects (in logs):

$$
\begin{gathered}
y_{t}=c_{1}\left(m_{t}-p_{t}\right)-c_{2}\left(e_{t}+p_{t}^{*}-p_{t}\right)+u_{t}, \\
y_{t}=a_{1}\left(y_{t}-\tau_{t}\right)+a_{2} g_{t}-a_{3} r_{t}+a_{4}\left(e_{t}+p_{t}^{*}-p_{t}\right)-a_{5} y_{t}+a_{6} y_{t}^{*}+\varepsilon_{t}, \\
m_{t}-p_{t}=b_{1} y_{t}-b_{2} r_{t}, \\
a_{3}\left(e_{t}+p_{t}^{*}-p_{t}\right)-a_{5} y_{t}+a_{6} y_{t}^{*}+k\left(r_{t}-r_{t}^{*}\right)=0,
\end{gathered}
$$

where $y_{t}$ and $y_{t}^{*}, p_{t}$ and $p_{t}^{*}$, and $r_{t}$ and $r_{t}^{*}$ are domestic and foreign output, and the price level and interest rate, respectively; $m_{t}$ is the money supply; $e_{t}$ is the nominal exchange rate; $g_{t}$ is the budget deficit; $\tau_{t}$ is the lump-sum tax; and $u_{t}$ and $\varepsilon_{t}$ are stochastic aggregate supply and demand shocks, respectively.

The aggregate supply $y_{t}$ is expanded by an increase in the real money supply $\left(m_{t}-p_{t}\right)$ and the real exchange rate appreciation (equation (1)). The financial effect $\left(c_{1}\right)$ reflects financial constraints in the real sector, with enterprises lacking access to the stock market. The exchange rate depreciation is contractionary $\left(c_{2}\right)$ 
as production is dependent upon the so-called critical import of raw materials, intermediate and investment goods etc. An increase in the foreign price level has the same impact and the impact of higher domestic prices is ambiguous. While there is a contractionary financial effect through a decrease in the real money supply, the real exchange rate appreciation has the opposite effect. Finally, the aggregate supply is affected by stochastic shock $u_{t}$.

Equation (2) relates the aggregate demand to disposable income, the budget deficit, the real interest rate, price and income effects in foreign trade, as well as stochastic shocks. Assuming a direct relationship between private expenditure and disposable income, an increase in taxes is contractionary $\left(a_{1}\right)$, which is a standard outcome for a non-Ricardian economy. A similar contractionary channel is provided by the relationship between income and imports $\left(a_{5}\right)$. The budget deficit is expansionary $\left(a_{2}\right)$, which can be the case when public debt is low. An increase in the real interest rate is restrictionary $\left(a_{3}\right)$, as it increases the cost of borrowing and creates incentives for the intertemporal substitution of private consumption and investments.

Improvement in relative prices is expansionary $\left(a_{4}\right)$, as any of three channels - depreciation of the exchange rate, an increase in foreign prices or a decrease in domestic prices - stimulates demand on domestic and foreign markets. Also, the aggregate demand benefits from an increase in output abroad $\left(a_{6}\right)$.

Equation (3) describes equilibrium in the financial (money) market. The money supply in real terms is equilibrated with the demand for money, which is an increasing function of higher output $\left(b_{1}\right)$ and a lower interest rate $\left(b_{2}\right)$. For simplicity, there is no difference between nominal and real interest rates in specifications for the goods and money markets, although it would be more appropriate to assume that demand for goods and services is dependent on the real interest rate, while demand for money is influenced by a nominal interest rate.

Equation (4) defines the balance-of-payments (BOP) equilibrium. The current account balance is equilibrated with the net capital inflows. It is assumed that capital flows are dependent on the interest rate differential. For the case of capital immobility $(k=0)$, the BOP equilibrium is achieved solely through the relative price adjustment (usually it implies a depreciation of the nominal exchange rate to correct the current account deficit). When the relative price mechanism is inefficient, there is no alternative to change in income as the BOP adjustment tool. For the current account deficit, a decline in income is necessary to improve the external balance through a decrease in demand for imports.

Despite its simplicity, the IS-LM-BP model is quite informative for the interpretation of macroeconomic developments in Ukraine's economy during the years 2010-2014. Graphic illustration is provided in Fig. 2. Until the middle of 
2011, there was an impression that post-crisis recovery of Ukraine's economy had been quite successful. Higher demand for exports and capital inflows allowed for a build-up of the foreign exchange reserves of the National Bank of Ukraine up to 38 bn USD. However, decreasing demand for the export of steel and chemicals created substantial problems from the middle of 2011. A simultaneous worsening of the BOP $\left(B P_{0} \rightarrow B P_{1}\right)$ and decrease in the aggregate demand $\left(I S_{0} \rightarrow I S_{1}\right)$ leads to a decline in income combined with an increase in the interest rate (т. B). More precisely, the magnitude of interest rate developments depends on the combined effect of worsening BOP and a decrease in the aggregate demand. Under a fixed exchange rate regime, as was the case in Ukraine, attaining a new macroeconomic equilibrium requires a decrease in the money supply $\left(L M_{0} \rightarrow L M_{1}\right)$.

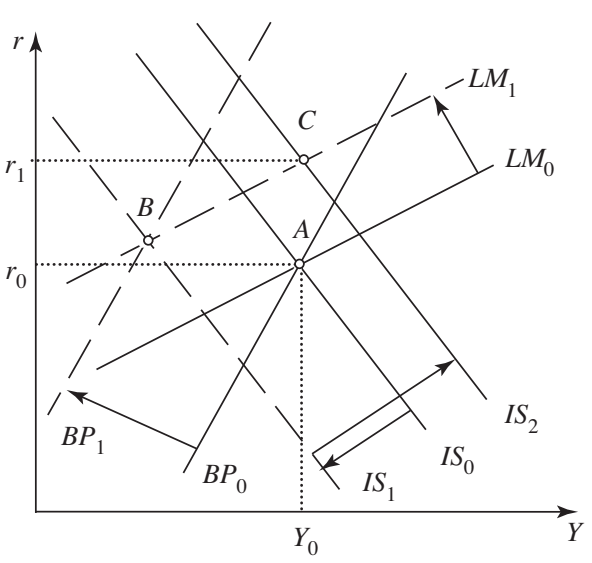

Fig. 2. Neutralisation of the Adverse Terms-of-trade Shock with an Increase in the Budget Deficit

Source: the authors' own elaboration.

If worsening of the terms-of-trade is perceived as temporary, it is tempting to compensate for declining foreign demand with an increase in the budget deficit $\left(I S_{1} \rightarrow I S_{2}\right)$. Such a policy provides an opportunity to restore the initial level of income, but at the cost of a substantial increase in the interest rate. However, that is not the only problem. For starters, the BOP disequilibrium is not eliminated, despite an increase in the interest rate. Second, it is necessary to proceed with a decrease in the money supply anyway. To sum up, keeping the economy at the level of income $Y_{0}$ leads to an increase in the interest rate, but it is not able to avoid a further loss of foreign exchange reserves. 

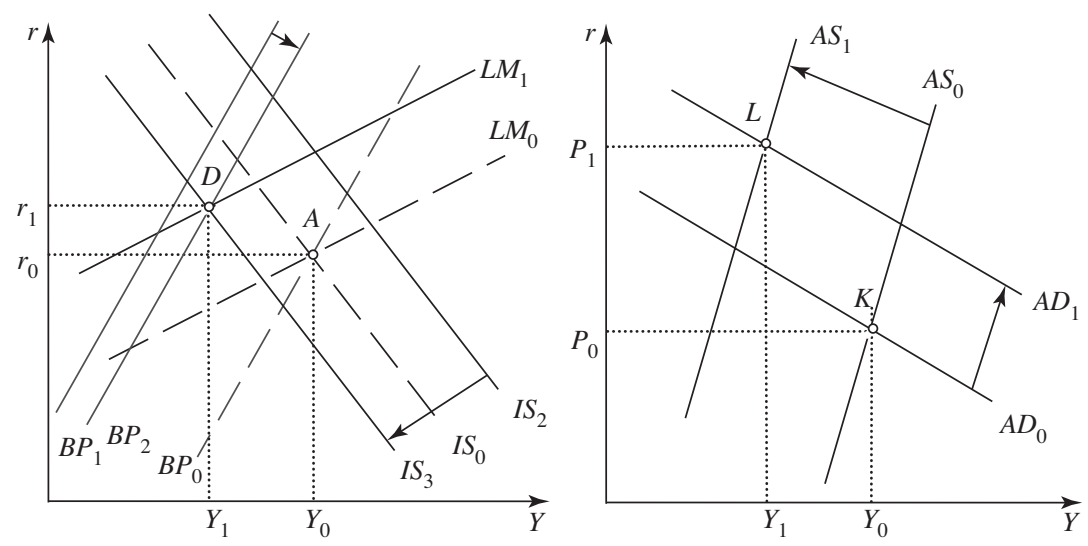

Fig. 3. Effects of the Exchange Rate Depreciation Source: the authors' own elaboration.

The depletion of the foreign exchange reserves leaves no other choice but to depreciate the exchange rate. Assuming a weak price effect in the aggregate supply $\left(s_{2}=0\right)$, a favourable change of the relative prices leads to an improvement in the current account that restores the initial level of income (Fig. 3). However, the situation is not so rosy if the negative supply-side effect of the exchange rate depreciation $\left(A S_{0} \rightarrow A S_{1}\right)$ is accounted for. In this case an increase in the aggregate demand does not bring the economy back to its equilibrium level, as an increase in the price level puts a constraint on the BOP improvement $\left(B P_{1} \rightarrow B P_{2}\right)$ and induces a decrease in the aggregate demand $\left(I S_{2} \rightarrow I S_{3}\right)$. For convenience, it is possible to assume that the effects of BOP improvement compensate for an opposite impact of the higher price level upon the real money supply.

\section{Data and Statistical Model}

The data includes the period from the first quarter of 1999 through the fourth quarter of 2013, using quarterly series of the nominal effective exchange rate (index, $2005=100$ ), the interest rate (\%), the budget balance (\% of GDP) and the gross domestic product - GDP (index, $1998=100$ ). The budget balance series were taken from Ukraine's Ministry of Finance data. All other data are obtained from the International Monetary Fund (IMF) International Financial Statistics online database. Since the GDP reveals a marked seasonal pattern, the series are seasonally adjusted using the X11 procedure. 
Table 1. Unit Root Test

\begin{tabular}{|c|c|c|c|c|c|c|c|c|}
\hline \multirow{3}{*}{ Lags } & \multicolumn{9}{|c|}{ Variables } \\
\cline { 2 - 9 } & \multicolumn{2}{|c|}{ exchange rate } & \multicolumn{2}{c|}{ interest rate } & \multicolumn{2}{|c|}{ budget balance } & \multicolumn{2}{c|}{ output } \\
\cline { 2 - 9 } & $\mathrm{L}$ & $\mathrm{FD}$ & $\mathrm{L}$ & $\mathrm{FD}$ & $\mathrm{L}$ & $\mathrm{FD}$ & $\mathrm{L}$ & FD \\
\hline 3 & -0.56 & $-3.10^{* *}$ & $-90.1^{*}$ & $-3.21^{* *}$ & -2.17 & $-4.50^{*}$ & -1.39 & $-3.81^{*}$ \\
\hline 6 & -0.47 & $-2.74 * * *$ & $-98.3^{*}$ & $-2.93^{*}$ & -2.19 & $-4.54^{*}$ & -1.39 & $-2.55^{* * *}$ \\
\hline 9 & -0.13 & $-3.83^{*}$ & $-80.41^{*}$ & $-3.67^{*}$ & -1.48 & $-3.69^{*}$ & -1.44 & -2.38 \\
\hline 12 & -0.25 & $-2.56^{* * *}$ & $-50.96^{*}$ & $-5.06^{*}$ & -1.41 & $-2.86^{* * *}$ & -1.26 & -1.86 \\
\hline
\end{tabular}

Note: ${ }^{*}$ null hypothesis of a unit root can be rejected at the $1 \%$ level of significance ${ }^{* *}$ at the $5 \%$ level of significance, ${ }^{* * *}$ at the $10 \%$ level of significance); L and FD stand for levels and first differences, respectively.

Source: the authors' own calculations.

The stationarity of variables is tested using the ADF unit root test procedure (Table 1). Except for the interest rate, for all series, the null of unit root cannot be rejected at 1 and 5\% statistical significance for their levels, while for first differences it can. As three out of four variables are found to be integrated of order 1 , it is necessary to investigate the cointegration relationship between them.

The Johansen cointegration test results for the nominal effective exchange rate, the interest rate, the budget balance and the GDP are presented in Table 2. According to the Maximum Eigenvalue Test, the hypothesis that there is a cointegration relationship between the variables is accepted for all test assumptions. Though it is suggested that three cointegrating equations be used at the $10 \%$ of statistical significance for the assumption of the quadratic trend, the result is rather weak, so the existence of one cointegrating equation is a much more plausible outcome.

Table 2. Johansen Cointegration Test (Maximum Eigenvalue Test)

\begin{tabular}{|l|c|c|c|c|c|}
\hline \multirow{2}{*}{$\begin{array}{c}\text { Hypothesized } \\
\text { no. of CE(s) }\end{array}$} & none & none & linear & linear & quadratic \\
\cline { 2 - 6 } & $\begin{array}{c}\text { no intercept } \\
\text { no trend }\end{array}$ & $\begin{array}{c}\text { intercept } \\
\text { no trend }\end{array}$ & $\begin{array}{c}\text { intercept } \\
\text { no trend }\end{array}$ & $\begin{array}{c}\text { intercept } \\
\text { trend }\end{array}$ & $\begin{array}{c}\text { intercept } \\
\text { trend }\end{array}$ \\
\hline None * & $30.32^{*}$ & $36.65^{*}$ & $36.03^{*}$ & $36.03^{*}$ & $35.63^{*}$ \\
\hline At most 1 & 14.74 & 14.76 & 13.13 & 13.19 & 10.21 \\
\hline At most 2 & 5.97 & 12.95 & 6.76 & 6.99 & 6.05 \\
\hline At most 3 & 1.61 & 5.84 & 1.82 & 3.07 & $2.91^{* * *}$ \\
\hline
\end{tabular}

Note: * denotes rejection of the null hypothesis at the $1 \%$ level of significance ${ }^{* *}$ at the $5 \%$ level of significance, ${ }^{* * *}$ at the $10 \%$ level of significance); two lags are used.

Source: the authors' own calculations. 
As the endogeneous variables are cointegrated, a VAR system with error correction (VECM) should be used. VECM methods use long-run information as a part of the identification process between cointegrated $I(1)$ variables, which allows for a more precise estimation of the functional relationships between endogenous variables.

If endogenous variables are $I(1)$ and cointegrated with rank $r(0<r<n)$, then the VECM representation is as follows:

$$
A(L) \Delta z_{t}=-\alpha \beta z_{t-1}+\varepsilon_{t},
$$

where $A(L)$ is the matrix polynomial with degree $k, \alpha$ and $\beta$ are $n \times r$ matrices of rank $r, z_{t}$ is the vector of endogenous variables, and $\varepsilon_{t}$ is the vector of stochastic innovations. Exact identification of $\beta$ requires $r$ restrictions on each of the $r$ cointegrating vectors.

The vectors of endogenous variables and stochastic innovations are chosen as follows:

$$
\begin{gathered}
z_{t}=\left(\Delta N E E R_{t}, \Delta R L_{t}, \Delta B D_{t}, \Delta Y\right), \\
\varepsilon_{t}=\left(\varepsilon_{t}^{N E E R}, \varepsilon_{t}^{R L}, \varepsilon_{t}^{B D}, \varepsilon_{t}^{Y}\right),
\end{gathered}
$$

where $N E E R_{t}$ is the nominal effective exchange rate, $R L_{t}$ is the lending rate, $B D_{t}$ is the budget balance, $Y_{t}$ is the real gross domestic product, $\varepsilon_{t}^{N E E R}, \varepsilon_{t}^{R L}, \varepsilon_{t}^{B D}$ and $\varepsilon_{t}^{Y}$ are stochastic innovations for respective endogenous variables, and $\Delta$ is the operator of first differences.

In addition to the lagged values of the endogenous variables, the VECMs include the world metals price index. It is expected that this variable accounts for major external demand shocks, as until recently the steel industry has accounted for about $40 \%$ of Ukraine's exports. Though as of 2013 the share of steel has declined to less than $30 \%$, it is still a significant part of Ukraine's exports.

Impulse responses are calculated from the vector moving average representation:

$$
z_{t}=A(L)^{-1} e_{t}=C(L) e_{t},
$$

where the leading matrix in $C(L)$ is the identity matrix.

According to the Akaike test, the optimal lag length is two.

\section{Empirical Results}

Estimates of the long-run cointegration relationships are as follows (a standard deviation of parameter estimates is given in the brackets):

$$
\begin{aligned}
& N E E R_{t}=1.058 R L_{t}-0.220 B D_{t}+10.694 Y_{t} . \\
& \begin{array}{lll}
(0.83) & (0.04) \quad(2.10)
\end{array}
\end{aligned}
$$


The cointegration relationship (7) implies that the nominal exchange rate is weakened by the budget deficit, higher interest rate and GDP. A direct relationship between the budget deficit and NEER is fairly consistent with the theoretical predictions of the IS-LM-BP model, as the resulting increase in the interest rate is insufficient to tap such capital inflows that would be enough to finance a corresponding widening of the current deficit brought about by a domestic demand shock. The same logic explains the direct link between the GDP and NEER. According the IS-LM-BP model, a higher interest rate should lead to strengthening of the exchange rate, which is not the case in our estimated long-run relationship. However, statistical significance of the coefficient on the interest rate in equation (7) is rather low, which suggests the importance of this causal link is not exaggerated.

Among independent variables, world metal prices contribute simultaneously to GDP growth and a decrease in the interest rate, while not affecting the NEER or budget balance. These results can be interpreted in such a way that the export receipts of the steel industries are monetised by the central bank. A resulting increase in the money supply brings about a combination of output growth and lower cost of lending.

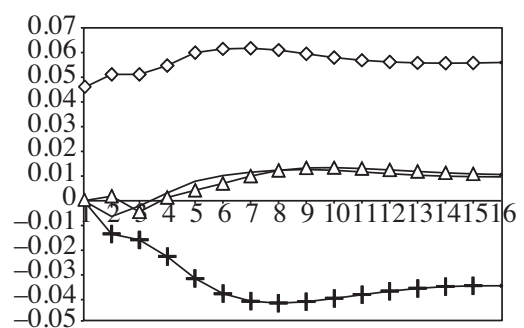

a) determinants of the NEER

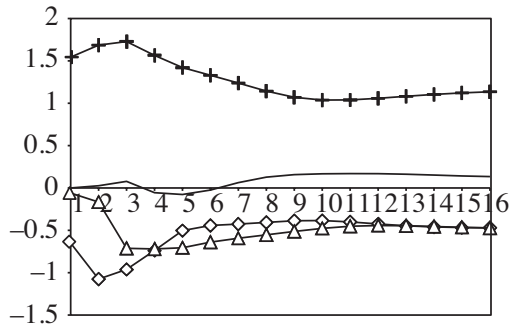

c) determinants of the budget balance

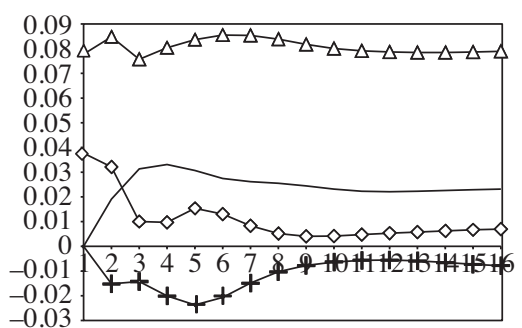

b) determinants of the interest rate

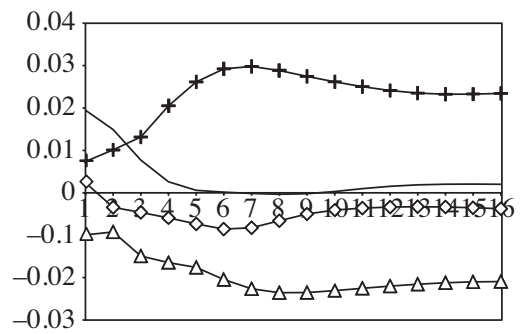

d) determinants of output (GDP)

$\multimap$ Exchange rate $\neg-$ Interest rate

— Budget balance Output

Fig. 4. Impulse Response Functions of Endogenous Variables

Source: the authors' own calculations. 
Fig. 4 presents the impulse-response functions for the endogenous variables. Similar to the long-run estimates (equation (7)), the NEER is weakened by output growth and a higher interest rate, which have very similar effects. Improvement in the budget balance leads to a prolonged strengthening of the NEER, which is sustained up to 16 periods. This suggests that fiscal discipline is an influential factor behind the exchange rate behaviour. Consequently, worsening of the budget balance since 2011 could be considered to be among the most realistic explanations for the spectacular exchange rate depreciation that has occurred since the beginning of 2014. The NEER seems to be very inertial, which is consistent with the logic of a de facto pegging to the U.S. dollar.

As implied by the IS-LM-BP model, a decrease in the interest rate is another effect of fiscal discipline. The maximum is achieved in four periods and then the effect gradually dies down. Both depreciation of the NEER and output growth are associated with an increase in the interest rate, though their effects follow different time patterns. Shocks to the exchange rate have an initial positive effect that gradually weakens over roughly eight quarters. The increasing effect on the shock to output gradually strengthens, achieving its long-run level in three quarters. As with the NEER, the interest rate is very inertial to its own shocks.

Table 3. Forecast Error Variance Decomposition Using the VECM

\begin{tabular}{|l|c|c|c|c|c|c|}
\hline \multirow{2}{*}{ Impulse } & \multirow{2}{*}{ Response to } & \multicolumn{5}{|c|}{ Forecast horizon } \\
\cline { 2 - 7 } & & 3 & 6 & 9 & 12 & 16 \\
\hline \multirow{3}{*}{$\begin{array}{l}\text { Nominal effective exchange } \\
\text { rate (NEER) }\end{array}$} & NEER & 93 & 82 & 75 & 72 & 71 \\
\cline { 2 - 7 } & $\mathrm{RL}$ & 0 & 0 & 1 & 2 & 2 \\
\cline { 2 - 7 } & $\mathrm{BD}$ & 6 & 16 & 22 & 24 & 25 \\
\cline { 2 - 7 } & $\mathrm{Y}$ & 1 & 2 & 2 & 2 & 2 \\
\hline Interest rate (RL) & $\mathrm{NEER}$ & 11 & 6 & 4 & 3 & 3 \\
\cline { 2 - 7 } & $\mathrm{RL}$ & 81 & 81 & 84 & 86 & 87 \\
\cline { 2 - 7 } & $\mathrm{BD}$ & 2 & 4 & 3 & 2 & 2 \\
\cline { 2 - 7 } & $\mathrm{Y}$ & 6 & 8 & 8 & 8 & 8 \\
\hline Budget balance (BD) & $\mathrm{NEER}$ & 22 & 18 & 16 & 15 & 15 \\
\cline { 2 - 7 } & $\mathrm{RL}$ & 5 & 10 & 11 & 12 & 12 \\
\cline { 2 - 7 } & $\mathrm{BD}$ & 73 & 73 & 73 & 73 & 73 \\
\cline { 2 - 7 } & $\mathrm{Y}$ & 0 & 0 & 0 & 0 & 0 \\
\hline \multirow{5}{*}{ Output (Y) } & $\mathrm{NEER}$ & 3 & 4 & 4 & 3 & 3 \\
\cline { 2 - 7 } & $\mathrm{RL}$ & 28 & 31 & 34 & 37 & 39 \\
\cline { 2 - 7 } & $\mathrm{BD}$ & 23 & 50 & 54 & 54 & 54 \\
\cline { 2 - 7 } & $\mathrm{Y}$ & 46 & 15 & 8 & 5 & 4 \\
\hline
\end{tabular}

Source: the authors' own calculations. 
The initial response of the budget balance after a shock to the exchange rate is negative, which argues against the use of currency depreciation as a convenient substitute for discrete cuts in government expenditure or tax hikes. The pattern of the reaction to the interest rate shock is very similar to that of NEER. An increase in the cost of debt servicing is among the obvious explanations. It is worth noting that the budget balance does not react to changes in output, as is customary for many high-income countries with a well-functioning tax system. The budget balance is quite inertial, though to a lesser extent if compared with the exchange rate or interest rate.

Finally, improvement in the budget balance is a strong factor behind an increase in output. The initial response achieves its maximum in five quarters, then somewhat weakens but remains significant going forward. As expected, the interest rate shock has a persistent negative effect upon the real sector. It seems that the exchange rate depreciation has a short-term restrictionary effect. Being fully accommodated within a year, output shocks are short-lived.

Table 3 presents the forecast error variance of the VECM endogenous variables. The budget balance explains an important share of the variation in the exchange rate (up to 25\%) and especially output (up to 53\%). On the other hand, the budget balance is operating under the influence of exchange rate and interest rate shocks, which account for $15-22 \%$ and $5-15 \%$ of the variation in budget balance, respectively. Among other results, the interest rate is slightly affected by the exchange rate and output shocks. In terms of the variance decompositions, fluctuations in Ukraine's output are significantly affected by the interest rate shock (up to 39\%), while the exchange rate shock is of minor importance (no more than $4 \%)$.

\section{Conclusions}

Based on the VECM estimated for the 1999-2013 period, it is established that the budget deficit is not expansionary in Ukraine, though it is a factor behind the exchange rate depreciation. The policy of fiscal prudence seems to be the principal driving factor of output growth, explaining above $50 \%$ of its variation. On the other hand, the budget balance is influenced by the exchange rate and interest rate, which together account for about a third of its variation. It is confirmed that an increase in output is of marginal importance for the budget balance.

Among other results, exchange rate depreciation seems to be contractionary in the real sector, but its impact on output is rather weak. At least there is no ground to expect any expansionary effects of a weaker currency in the particular case of Ukraine's economy, despite the considerable international evidence in favour 
of devaluation as a tool for achieving internal and external equilibrium. The interest rate increases along with exchange rate depreciation and output growth, but these factors explain together less than $20 \%$ of the variation in the cost of loans. Besides fiscal discipline, a decrease in the interest rate is the principal driving factor of output growth in Ukraine.

On the whole, our findings provide us with strong arguments in favour of fiscal discipline in Ukraine as a stabilisation policy tool. This contrasts with the realities of actual fiscal policies used in the 2012-2013 period.

\section{Bibliography}

Adao B., De Brito. J. (2006), The Effects of a Government Consumption Shock, Economic Bulletin, Banco de Portugal, Lisboa.

Afonso A. (2010), Expansionary Fiscal Consolidations in Europe: New Evidence, "Applied Economic Letters", vol. 17, no. 2, http://dx.doi.org/10.1080/13504850701719892.

Alesina A., Ardagna S. (2009), Large Changes in Fiscal Policy: Taxes versus Spending, "NBER Working Paper", no. 15438, National Bureau of Economic Research, Cambridge, Mass., http://dx.doi.org/10.3386/w15438.

Bergman B., Hutchison M. (2010), Expansionary Fiscal Contractions: Re-evaluating the Danish Case, "International Economic Journal”, vol. 24, no. 1 (March), http://dx.doi. org/10.1080/10168731003589857.

Blanchard O., Perotti R. (2002), An Empirical Characterization of the Dynamic Effects of Changes in Government Spending and Taxes on Output, "Quarterly Journal of Economics", vol. 117, no. 4, http://dx.doi.org/10.1162/003355302320935043.

Chen Y. (2008), Assessing the Effects of Monetary and Fiscal Shocks: The Polish Experience, "International Research Journal of Finance and Economics", no. 17.

Dai Q., Philippon T. (2005), Fiscal Policy and the Term Structure of Interest Rate, "NBER Working Paper", no. 11574, National Bureau of Economic Research, Cambridge, Mass., http://dx.doi.org/10.3386/w11574.

Enache C. (2009), Fiscal Policy and Economic Growth in Romania, "Annales Universitatis Apulensis Series Oeconomica", vol. 11, no. 1.

Fischer S. (1993), The Role of Macroeconomic Factors in Growth, "Journal of Monetary Economics", vol. 32, no. 3, http://dx.doi.org/10.1016/0304-3932(93)90027-d.

Gemmell N., Kneller R., Sanz I. (2007), Fiscal Policy Impacts on Growth in the OECD: Are They Long-Run? University of Nottingham, Nottingham.

Giavazzi F., Jappelli T., Pagano M. (2000), Searching for Non-linear Effects of Fiscal Policy: Evidence from Industrial and Developing Countries, "European Economic Review”, vol. 44, no. 7, http://dx.doi.org/10.1016/s0014-2921(00)00038-6.

Giavazzi F., Pagano M. (1990), Can Severe Fiscal Contractions Be Expansionary? Tales of Two Small European Countries, "NBER Macroeconomics Annual”, National Bureau of Economic Research, Cambridge, Mass., http://dx.doi.org/10.2307/3585133.

Hsing Y. (2006), Macroeconomic Policies and Output Fluctuations in Slovakia: Application of the Taylor Rule, "RISEC", vol. 53, no. 2. 
Kandil M. (2009), Public Spending and the Macroeconomy: Evidence from Developing and Developed Countries, "International Journal of Business and Economics", vol. 8, no. 2 .

Lendvai J. (2007), The Impact of Fiscal Policy in Hungary, "ECFIN Country Focus", vol. IV, no. 11.

Perotti R. (2002), Estimating the Effects of Fiscal Policy in OECD Countries, "ECB Working Paper", no. 168, European Central Bank, Frankfurt.

Reznykova O. O. (2004), Perspektyvy hlobal'noho rozvytku u 2014 rotsi: wysnovky dlya Ukrayiny, "Stratehichni priorytety", no. 1(31).

Romer C., Berstein J. (2009), The Job Impact of the American Recovery and Investment Plan, "The American Economic Review: Papers and Proceedings", vol. 99, no. 2 (May).

Romero-Avila D., Strauch R. (2008), Public Finances and Long-term Growth in Europe: Evidence from a Panel Data Analysis, "European Journal of Political Economy", vol. 24, no. 1, http://dx.doi.org/10.1016/j.ejpoleco.2007.06.008.

Rukelj D. (2009), Modelling Fiscal and Monetary Policy Interactions in Croatia Using Structural Vector Error Correction Model, "Privredna kretanja i ekonomska politika", no. 121.

Rzońca A., Ciżowicz P. (2005), Non-Keynesian Effects of Fiscal Contraction in New Member States, "ECB Working Paper”, no. 519, European Central Bank, Frankfurt.

Segura-Ubiergo A., Simone A., Gupta S. (2006), New Evidence on Fiscal Adjustment and Growth in Transition Economies, "IMF Working Papers", no. 06/244, International Monetary Fund, Washington, http://dx.doi.org/10.5089/9781451865042.001.

Shevchuk V., Kopych R. (2010), Capital Mobility and the Budget Deficit Macroeconomic Effects in The Central and East European Countries (in:) Quantitative Methods in Socio-Economic Analysis, ed. by E. Sodomova, 16th Slovak-Polish-Ukrainian Scientific Seminar, University of Economics, Bratislava.

Vozna L. Yu, Zhalilo Ya. A. (2004), Biznes-tsykl yak fenomen ukrayin'skyi ekonomiky: peredumovy formuvanya ta vysnovky dya politykiv, "Stratehichni priorytety", no. 2(31).

Wojciechowska-Toruńska I. (2009), Związek wzrostu gospodarczego i deficytu sektora finansów publicznych (in:) Gospodarka w warunkach kryzysu, ed. by S. Antkowicz, M. Pronobis, Wyższa Szkoła Bankowa, Gdańsk.

\section{Wewnętrzne i zewnętrzne wstrząsy popytowe w gospodarce ukraińskiej (Streszczenie)}

Utrzymujący się deficyt budżetowy oraz ekstremalnie wysokie stopy procentowe jako skutek bardzo niskiej inflacji stanowią wyraźną cechę gospodarki ukraińskiej w latach 2010-2013. Wykorzystując metodę autoregresji wektorowej z korektą błędu (VAR/VEC), ustalono, że: a) deficyt budżetowy jest czynnikiem deprecjacji kursu walutowego oraz wzrostu poziomu stopy procentowej, a także mocnego negatywnego oddziaływania na wzrost gospodarczy; b) wzrost stopy procentowej powoduje pogorszenie się bilansu budżetowego oraz znaczący spadek produkcji (oba rezultaty to standardowe makroekonomiczne relacje); c) deprecjacja kursu walutowego powoduje permanentne pogorszenie się bilansu budżetowego oraz przejściowy wzrost stopy procentowej i obniżenie poziomu dochodu. Warto zwrócić uwagę, że presja w kierunku wzrostu stopy procentowej okazała 
się jedynym statystycznie istotnym skutkiem wzrostu dochodu (PKB). Według wariancji reszt bilans budżetowy wyznacza do 50\%, a stopa procentowa do $40 \%$ zmian dochodu. Potwierdzono, że wzrost dochodu nie ma wpływu na bilans budżetowy. Ogólnie mówiąc, otrzymane wyniki świadczą na korzyść dyscypliny fiskalnej w gospodarce ukraińskiej jako narzędzia polityki stabilizacyjnej.

Słowa kluczowe: bilans budżetowy, kurs walutowy, stopa procentowa, dochód, Ukraina. 